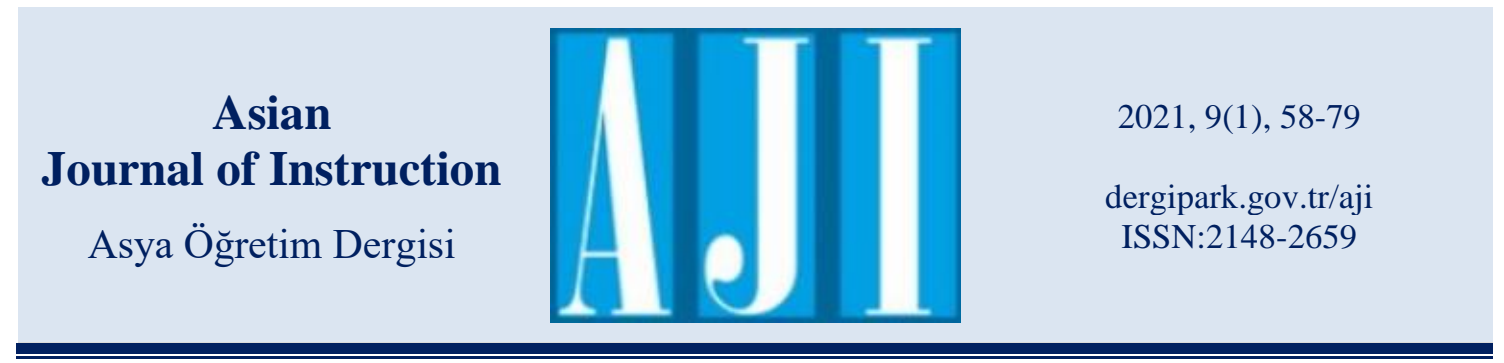

\title{
Pedagojik Formasyon Sertifika Programına Yönelik Sorunlar ve Çözüm Önerileri: Öğretim Elemanlarının Bakış Açısı
}

\author{
Gürcü Erdamar'1, Özlem Tengilimoğlu²
}

\author{
Erdamar, G., \& Tengilimoğlu, Ö. (2021). Pedagojik formasyon sertifika programına yönelik sorunlar ve çözüm \\ önerileri: Öğretim elemanlarının bakış açısı. Asya Öğretim Dergisi, 9(1), 58-79. \\ https://doi.org/10.47215/aji.834650
}

\section{$\ddot{O} z$}

Bu çalışmanın amacı Pedagojik Formasyon Sertifika Programında (PFSP) ders veren öğretim elemanlarının görüşleri bağlamında, programın etkililiğini incelemek, yaşanan sorunları ortaya çıkarmak ve eğer PFSP'ler ileride tekrar açılacaksa, niteliğini artıracak öneriler sunmaktır. Nitel araştırma yöntemlerinden durum çalışmasının tercih edildiği çalışmada, bir devlet üniversitesinin eğitim fakültesinde PFSP'de ders veren öğretim elemanlarının görüşlerine başvurulmuştur. Buna göre araştırmanın çalışma grubunda, bir devlet üniversitesinin eğitim fakültesinde görev yapan farklı anabilim dallarından 17 öğretim elemanı yer almıştır. Katılımcıların seçiminde amaçlı örnekleme yöntemlerinden ölçüt ve maksimum çeşitlilik örnekleme yöntemleri kullanılmıştır. Veriler yarı yapılandırılmış görüşme formu aracılığı ile toplanmış, verilerin analizinde içerik analizi kullanılmıştır. Araştırmanın sonunda PFSP'nin nitelikli öğretmen yetiştirme amacına ulaşmasında sorunlar olduğu görülmüştür. Öğretim elemanlarına göre, PFSP'de yaşanan en önemli sorunlar öğrenme-öğretme süreci, öğrenci, ders içerikleri, değerlendirme, ögretmenlik uygulaması, genel sorunlar ve öğretim elemanı temalarında yoğunlaşmaktadır. PFSP'nin niteliğini artırmak ve yaşanan sorunları çözebilmek için öncelikle PFSP'ye bakış açısının değiştirilmesi gerekmektedir. Öğretim elemanları PSPF'yi para kazanma yollarından birisi olarak, öğrenciler de ücret karşılığında alınan bir belge olarak görmekten vazgeçmelidir. PFSP'de ders verecek ögretim üyelerini belirlerken alan uzmanlıklarının dikkate alınması önerilmektedir. PFSP'nin süresi ve uygulamalı saatleri artırılmalı, kalabalık sınıflar yerine öğrencilerin branşları dikkate alınarak dersler küçük gruplarda yürütülmelidir.

Anahtar Kelimeler: Öğretmen eğitimi, pedagojik formasyon sertifika programı, öğretim elemanı görüşleri, durum çalışması

\section{Problems and Suggestions Regarding the Pedagogical Formation Certificate Program: Perspectives of Teaching Staff}

\begin{abstract}
The purpose of this study is that to examine the efficiency of the program, reveal problems, and give suggestions about increasing the quality of in the context of opinions of teaching staff giving lectures in scope of Pedagogical Formation Certificate Program (PFCP) in case it is put into force again in the future. In this study, where one of the qualitative research methods. Case study is chosen, opinions of teaching staff who give lectures in scope of PFCP of different department of a public university, are asked. In working group of the study, there were 17 taching staff of a
\end{abstract}

${ }^{1}$ Prof. Dr., Gazi Üniversitesi Gazi Eğitim Fakültesi, https://orcid.org/0000-0001-6753-0151, gurkoc@gazi.edu.tr

2 Öğretmen, Milli Eğitim Bakanlı̆̆ı, https://orcid.org/0000-0003-0088-8049, tengilimogluozlem@ @mail.com 
Pedagojik Formasyon Sertifika Programına Yönelik Sorunlar ve Çözüm Önerileri: Öğretim Elemanlarının Bakış Açısı

public university working in different departments, semi-structured interview form is used to gather data, content analysis is done for the analysis of the gathered data. Criterion and maximum variation methods are used for selecting participants. At the end of research, it is observed that PFCP is unable to achieve the goal of raising a qualified teacher and PFCP lecturers find it unnecessary. According to lecturers, the problems of PFCP are mostly about learningteaching process, students, lesson contents, asessment, teaching practices, general problems and teaching staffs. In order to increase the quality of PFCP and to solve the problems experienced, first of all, the perspective towards PFCP should be changed. Teaching staff should stop seeing PFCP as one of the ways to earn money, and students as a certificate received for a fee. It is recommended to consider their field expertise while determining the faculty members who will teach in the PFCP. The duration and practical hours of the PFSP should be increased, and the lessons should be conducted in small groups, taking into account the branches of the students instead of crowded classes.

Keywords: Teacher education, pedagogical formation certificate program, teaching staffs' opinions, case study

\section{Giriş}

Türkiye'de öğretmen yetiştirme görevi 1982 yılından itibaren ağırlıklı olarak eğitim fakültelerinde gerçekleştirilmektedir. Ancak ülkemizde başta fen-edebiyat fakültesi olmak üzere eğitim fakülteleri dışındaki diğer fakültelerden mezunların da öğretmen olmasının yolunu açan bir uygulama göze çarpmaktadır. Pedagojik formasyon sertifika programı (PFSP) adı altında yürütülen bu uygulama ile herhangi bir lisans derecesine sahip bir birey, bu programa katılarak öğretmenlik mesleğine dâhil olabilme olanağına kavuşmaktadır. 1992 y1lında eğitim yükssekokullarının eğitim fakültesine dönüştürülmesi ve sınıf öğretmenliği bölümlerinin eğitim fakültelerine bağlanması ile sınıf öğretmenliği bölümleri birkaç yıl mezun verememiştir. Bunun üzerine MEB'in talebi ile sınıf öğretmeni açığının giderilmesi amacıyla 26 hafta süren ve 21 kredilik PFSP uygulanmaya başlanmıştır. Ancak bazı üniversitelerde PFSP'nin 26 haftadan daha az sürdüğü ve bir süre sonra ihtiyaçtan daha fazla öğrenciye sınıf öğretmenliği sertifikası verildiği görülmüsstür (YÖK, 2007). Bu durum ise PFSP'nin amacının ve niteliğinin sorgulanmasına yol açmıştır.

PFSP 1997 yılında kaldırılarak (YÖK, 1998), fen-edebiyat mezunları için 4+1.5 y1l olacak şekilde tezsiz yüksek programına dönüştürülmüş, 2008 yılında PFSP'nin süresi bir yıla indirilmiş (YÖK, 2008), Yüksek Öğretim Kurulu'nun (YÖK) 2010 yılında aldığı bir kararla tezsiz yüksek lisans uygulamasından vazgeçilerek yeniden PFSP iki yarı yıl olarak uygulanmaya devam edilmiştir. Ayrıca önceden yalnızca mezunlara tanınan formasyon hakkı, 2010 yılındaki değişiklik ile fen-edebiyat fakültesi öğrencilerine de verilmiştir (YÖK, 2010). 2012 tarihli Yükseköğretim Genel Kurul Toplantısında yeni PFSP açılmamasına ve önceden açılanların öğrencilerin işlemleri bittikten sonra kapatılmasına karar verilmiştir (YÖK, 2012). Ancak, bir yıl sonra bu fikirden yine vazgeçilerek, PFSP'ye devam edilmiştir. 2010 ile 2013 yılları arasında PFSP ile ilgili birbirinin tam tersi beş karar alındığı, bu durumun da eğitim camiasında ve öğretmen adaylarında büyük bir karmaşa yarattığı görülmektedir (Yıldırım \& Vural, 2014: 81). 2015 yılında aldığı bir kararla YÖK, formasyon kontenjanlarını üniversite senatolarına bırakmış, bu kararla birlikte kontenjanlar azalacağına daha da artış göstermiştir. Bazı üniversitelerde kontenjanların 5000 gibi sayılara geldiği bildirilmektedir (YÖK, 2015). YÖK, 2015-2016 öğretim yılında 108 üniversiteye PFSP açma yetkisi vermiş, 2018 yılında ise ölçütleri karşılayan tüm fakültelere belli ölçüde kontenjan tanımıştır (YÖK, 2018). 2017 yılında alınan tartışmalı bir kararla pedagojik formasyon eğitimine başlamış ama henüz tamamlamamış, KPSS'den 75 ve üzeri puan alan adayların öğretmen olabilmesinin yolu açılmıştır (Talim ve Terbiye Kurulu, 2017). 29.06.2020 tarihli ve 12 sayılı Talim Terbiye Kurulu Kararı ile PFSP'nin iptal edildiği, tekrar tezsiz yüksek lisans programlarına dönüş yapıldığı görülmektedir (YÖK, 2020). Ülkemizde, öğretmen eğitiminde gerçekleştirilen bu birbirine zit değişiklikler, nitelikli öğretmen yetiştirmenin önünde ciddi engeller oluşturmaktadır. 
Asıl amac1 öğretmen yetiştirme olmayan fakültelere verilen pedagojik formasyon eğitimi, beraberinde sorunları da getirmiştir. Özellikle ortaöğretim alan öğretmenliklerinde ihtiyaçtan fazla öğretmen adayı mezun olmaya başlamıştır. Safran'ın da (2014: 3) belirttiği gibi fenedebiyat fakültesi öğrencilerinin ve fakülte yöneticilerinin baskısı ile açılan PFSP, eğitim fakültesi mezunlarının istihdam sorununu daha da derinleştirmektedir. PFSP'ye katılan fenedebiyat fakültesi öğrencileri ve mezunları, atanamayan öğretmen adayı sayısının daha da artmasına yol açmıştır (Yüksel, 2011). Sorunun sadece nicel artış olduğu düşünülmemelidir. PFSP'de verilen eğitimin niteliğinin ve öğretmen adaylarının mesleki yeterliklerinin de gözden geçirilmesi gerekmektedir (Yıldırım \& Vural, 2014). Eğitim fakültesinde iki döneme yayılan öğretmenlik uygulaması, PFSP'de ön koşulu olan dersler alınmadan ve tek dönemde gerçekleştirilmeye çalışılmaktadır. PFS eğitimi alan öğrencilerin, bu eğitim sonrası öğretmen olarak atanma olasılıklarının az olduğunu düşünmeleri, eğitim veren öğretim elemanlarının ders yüklerinin artması (Kiraz \& Dursun, 2015: 1024-1025) ve aslında bu eğitimi gereksiz bulmaları, güdülenmelerinin düşmesine yol açmaktadır (Yılmaz, 2015).

Alan yazın incelendiğinde, PFSP'ye yönelik araştırmaların önemli bir bölümünün öğretmen adaylarının mesleğe yönelik tutumlarına (Bircan, 2019; Durmuşçelebi, 2015; Kanadlı \& Karakuş, 2016) ve PFSP'ye ilişkin görüşlerine (Demirtaş \& Kırbaç, 2016; Filiz \& Durnali, 2019; Kiraz \& Dursun, 2015; Taneri, 2016) yönelik olduğu görülmektedir. Bir grup çalışmada ise eğitim fakültesi öğrencileri ile pedagojik formasyon eğitimi alan öğrencilerin mesleğe yönelik tutumları karşılaştırılmıştır (Öztürk, Doğan \& Koç, 2005; Şen \& Göğüş, 2011). Pedagojik formasyon eğitimi alan öğretmen adaylarının öğretmenlik uygulamasına yönelik görüşleri (Kılınç, Kılcan \& Tepeli, 2018; Tepeli \& Caner, 2014), meslek tercih nedenleri (Yiğit, 2018), pedagojik/mesleki yeterlik düzeyleri/algıları (Atmaca, 2019; Çocuk, Yokuş \& Tanrıseven, 2015), mesleğe yönelik motivasyonları (Altınkurt, Yılmaz \& Erol, 2014; Y1ldırım, Alpaslan \& Ulubey, 2019) konularında da çalışmalar bulunmaktadır. Buna göre çalışmaların PFSP'ye katılan öğrencilerin mesleğe yönelik algıları/tutumları ve aldıkları eğitime yönelik görüşlerine yoğunlaştığı anlaşılmaktadır. PFSP'de görev alan öğretim elemanlarının görüşlerinin alındığı çalışmalar oldukça sınırlıdır. Bu konuda son zamanlarda birkaç araştırmanın yapıldı̆̆ görülmektedir (Atmaca, 2019; Doğanay vd., 2015; Gürol, Türkan \& Som, 2018; Köse, 2017). Oysa eğitim alan öğrenciler kadar eğitim veren paydaşların da eğitim programı ile ilgili görüşlerine başvurmak gerekir. Bu çalışmanın amacı Ankara'daki büyük bir devlet üniversitesinde PFSP'de ders veren öğretim elemanlarının görüşleri bağlamında, programın etkililiğini incelemek, yaşanan sorunları ortaya çıkarmak ve eğer PFSP'ler ileride tekrar açılacaksa, niteliğini artıracak öneriler sunmaktır.

\section{Yöntem}

\subsection{Araştırma Modeli}

Araştırmada öğretim elemanlarının pedagojik formasyon eğitimine yönelik deneyimleri derinlemesine analiz edilmeye çalışıldığı için nitel araştırma yöntemlerinden durum çalışması kullanılmıştır. $\mathrm{Bu}$ doğrultuda PFSP'nin amacına ulaşıp ulaşmadığı ve uygulamada yaşanan durumlaranlaşılmaya çalışılmıştır (Creswell, 2013: 97). Bu çalışmada öğretim elemanlarının pedagojik formasyon programının amacına uygunluğu, gerekliliği, programda yaşanan sorunlar ve önerilerine ilişkin görüşlerini ayrıntılı olarak betimlemek amaçlanmıştır.

\subsection{Katılımcilar}

Araştırmanın çalışma grubunu bir devlet üniversitesinin eğitim fakültesinde PFSP'de ders veren öğretim elemanları oluşturmaktadır. Sekiz anabilim dalından 11 erkek, altı kadın toplam 17 öğretim elemanıyla görüşmeler yapılmıştır. Öğretim elemanlarının seçiminde ölçüt örnekleme 
Pedagojik Formasyon Sertifika Programına Yönelik Sorunlar ve Çözüm Önerileri: Öğretim Elemanlarının Bakış Açısı

kullanılmıştır. Ölçütler 2017-2018 öğretim yılında PFSP'de ders vermiş olmak ve araştırmaya gönüllü olarak katılmaktır. Öğretim elemanlarına ilişkin demografik bilgiler Tablo 1'de yer almaktadir:

Tablo 1. Öğretim Elemanlarına İliş̧kin Demografik Bilgiler

\begin{tabular}{lllll}
\hline Katılımcı & Cinsiyet & \multicolumn{1}{c}{ Kıdem } & \multicolumn{1}{c}{ Unvan } & \multicolumn{1}{c}{ Anabilim Dalı } \\
\hline Ö1 & Erkek & $21+$ & Prof.Dr. & Eğitim Yönetimi \\
\hline Ö2 & Erkek & $11-15$ & Dr.Öğr.Üyesi & Fizik \\
\hline Ö3 & Erkek & $11-15$ & Doç.Dr. & Eğitimde Ölçme ve Değerlendirme \\
\hline Ö4 & Kadın & $11-15$ & Doç.Dr. & Eğitim Programlar1 ve Öğretim \\
\hline Ö5 & Erkek & $21+$ & Prof.Dr. & Eğitim Programları ve Öğretim \\
\hline Ö6 & Erkek & $11-15$ & Dr.Öğr.Üyesi & Sınıf Eğitimi \\
\hline Ö7 & Kadın & $16-20$ & Doç.Dr. & Eğitim Programlar1 ve Öğretim \\
\hline Ö8 & Erkek & $16-20$ & Prof.Dr. & Türkçe \\
\hline Ö9 & Erkek & $21+$ & Prof.Dr. & Rehberlik ve Psikolojik Danışmanlık \\
\hline Ö10 & Kadın & $16-20$ & Prof.Dr. & Eğitim Programlar1 ve Öğretim \\
\hline Ö11 & Kadın & $16-20$ & Doç.Dr. & Eğitim Programlar1 ve Öğretim \\
\hline Ö12 & Kadın & $10-$ & Öğr.Gör.Dr. & Eğitim Programlar1 ve Öğretim \\
\hline Ö13 & Kadın & $10-$ & Öğr.Gör.Dr. & Eğitim Programlar1 ve Öğretim \\
\hline Ö14 & Erkek & $10-$ & Dr.Öğr.Üyesi & Sinıf Eğitimi \\
\hline Ö15 & Erkek & $16-20$ & Doç.Dr. & Türkçe \\
\hline Ö16 & Erkek & $11-15$ & Dr.Öğrt.Üyesi & Sosyal Bilgiler Eğitimi \\
\hline Ö17 & Erkek & $16-20$ & Prof.Dr. & Ĕğitim Yönetimi \\
\hline
\end{tabular}

Çalışma grubundaki öğretim elemanlarının 11'i erkek, 6'sı kadındır. 6'si 16-20 yıl, 5'i 11-15 y1l, 3'ü 21 y1l ve üzeri, 3'ü ise 10 yıl ve altı kıdeme sahiptir. Unvanlara bakıldığında katılımcılardan 6'sının Prof. Dr., 5'inin Doç. Dr., 4'ünün Dr. Öğretim Üyesi ve 2'sinin Öğretim Görevlisi Dr. olduğu görülmektedir. Öğretim elemanları, Eğitim Programları ve Öğretim Anabilim Dalı ağırlıklı olmak üzere sekiz anabilim dalında görev yapmaktadır.

\subsection{Veri Toplama Araçları}

Araştırmanın verileri yarı yapılandırılmış görüşme formu ile toplanmıştır. Öncelikle ilgili alanyazın taranarak taslak bir görüşme formu hazırlanmıştır. Daha sonra soruların anlaşılırlığ ve veri toplama gücü açısından dört Eğitim Programları ve Öğretim uzmanından (biri Prof. Dr., üçü Doç. Dr. unvanlı, ikisi aynı zamanda pedagojik formasyon programında ders veren) görüş alınmıştır. Bir öğretim elemanı ile pilot çalışma gerçekleştirilerek görüşme formuna son şekli verilmiştir. Buna göre görüşme formunda pedagojik formasyon programının amacına uygunluğu, gerekliliğii, derslerin nasıl işlendiği, nasıl değerlendirildiğgi, öğrencilerin derslere yönelik tutumları, programda yaşanan genel sorunlar ve önerilere ilişkin sorular yer almıştır. Çalışma PFSP'de yaşanan sorunlara odaklanmıştır. Bu nedenle görüşme soruları, sorunları ortaya çıkarmaya yoğunlaşmıştır. Örneğin 'PFSP'de dersler nasıl işlenmektedir? Yaşanan en önemli sorunlar nelerdir?" gibi sorular sorulmuştur.

\subsection{Veri Toplama Süreci}

Veriler katılımcılarla yüz yüze görüşme yapılarak toplanmış ve kayıt altına alınmıştır. Görüşmeler yaklaşık 35-40 dakika sürmüştür. Katılımcıların sorulara içten ve gerçekçi cevap vermelerini sağlamak için isimlerinin gizli tutulacağı ve hiçbir şekilde açıklanmayacağ belirtilmiştir. Katılımcıların gönüllü olmaları araştırmanın geçerliliği ve güvenirliğini sağlama açısından önemli bir unsurdur. Bu noktada öğretim elemanlarının seçiminde gönüllülük esas 
alınmıştır. Ayrıca yalnızca izin veren katılımcılar için ses kaydı alınmış, izin vermeyen katılımcıların görüşleri elle not alınmıştır.

\subsection{Verilerin Analizi}

Verilerin analizinde içerik analizi tekniği kullanılmıştır (Yıldırım \& Şimşek, 2013: 259). İçerik analizinin mantığı temelde birbirine benzeyen verileri belirli temalar ve kodlar çerçevesinde gruplamaktır. Görüşmeler, günlükler ve doküman analizi gibi metin analizlerinde içerik analizi sıklıkla tercih edilmektedir (Patton, 2014: 453). İçerik analizi yapılırken önce her bir görüşme için veriler kodlanmış, ardından sınıflamalar yapılmış ve üçüncü aşamada ise kod ve kategori (tema) tabloları oluşturulmuştur. Öğretim elemanları Ö1, Ö2, Ö3, ....... olarak kodlanmıştır. Tablolarda yer alan frekanslar, görüş bildiren öğretim elemanı sayılarını vermektedir.

\subsection{Geçerlik ve Güvenirlik}

Nitel çalışmalarda geçerlik ve güvenirliğin sağlanması önemlidir. Geçerliğin sağlanması için, katılımcılara kendi görüşmelerinin metinleri gösterilmiş ve ifadelerinin doğruluğuna yönelik teyit alınmıştır. İki araştırmacı verileri birbirinden bağımsız olarak kodlamış ve kodların uyuşum yüzdesi hesaplanmıştır. Çalışmanın güvenirlik hesaplamasında Miles \& Huberman (1994: 64), Uyuşum Yüzdesi Formülü kullanılmış $[\mathrm{P}=(\mathrm{Na} / \mathrm{Na}+\mathrm{Nd})$ x 100] (P: Uyuşum Yüzdesi, Na: Uyum Miktarı, Nd: Uyuşmazlık Miktarı) ve uyuşum yüzdesi \%82 olarak bulunmuştur. Araştırmanın iç güvenirliğini artırmak için veriler doğrudan alıntılarla desteklenmiştir.

\subsection{Etik Kurul İzin}

Çalışmanın verileri 2020 yılı öncesinde toplanmıştır. Araştırmaya katılan öğretim elemanlarına araştırmanın konusu, amacı ve tüm bilgilerin gizlilik ve mahremiyet ilkelerine uygun olarak gizli tutulacağı konusunda gerekli açıklamalar yapılarak, yazılı onamları alınmıştır.

\section{Bulgular}

Araştırmadan elde edilen verilerin analizi sonucunda ulaşılan bulgular ve bu bulgulara ilişkin yorumlar, temalar doğrultusunda PFSP'nin amacı ve gerekliliği, programa ilişkin sorunlar ve öneriler şeklinde ele alınmıştır.

\subsection{PFSP'nin Amacı ve Gerekliliği}

Öncelikle öğretim elemanlarına PFSP'nin amacının ne olduğu, amacına ulaşıp ulaşmadığı sorulmuştur. Verilen yanttlar Tablo 2'de sunulmuştur:

Tablo 2. Pedagojik Formasyon Programının Amacına İlişkin Görüşler

\begin{tabular}{lll}
\hline \multicolumn{1}{c}{ Tema } & \multicolumn{1}{c}{ Kod } & n \\
\hline İdeal Amacı & Nitelikli öğretmen yetiştirme & 17 \\
\hline Amacına Ulaşma & Hayır & 14 \\
Durumu & Evet & 3 \\
\hline \multirow{3}{*}{ Uygulamadaki Amacı } & Fen-Edebiyat mezunlarına iş imkanı oluşturma çabası & 11 \\
& Lisans düzeyinde verilemeyen eğitimi tamamlama çabası & 4 \\
& Para kazanmak için/ekonomik kaygılarla verilmesi & 2 \\
\hline
\end{tabular}

Tablo 2'ye göre öğretim elemanları PFSP'nin ideal amacının iyi bir öğretmen yetiştirmek olması gerektiğini önemle vurgulamıştır. Ama öğretim elemanlarının çoğu PFSP'nin amacına 
Pedagojik Formasyon Sertifika Programına Yönelik Sorunlar ve Çözüm Önerileri: Öğretim Elemanlarının Bakış Açısı

ulaşamadığını belirtmektedir. Başka bir deyişle öğretim elemanları PFSP'nin nitelikli öğretmen yetiştirme amacına hizmet etmediği görüşündedir. Onlara göre PFSP'nin uygulamadaki amac1 fen-edebiyat fakültesi mezunlarına iş bulabilmektir. İki öğretim elemanı ise fakülte yönetimlerinin ve bazı öğretim elemanlarının PFSP'yi öğretmen yetiştirme değil para kazanma aracı olarak gördügünü belirtmektedir. Öğretim elemanlarının görüşlerinden bazıları aşağıda yer almaktadir:

"Maalesef Türkiye'de Fen Edebiyat Fakülteleri kuruluş amacina uygun eylemlerde bulunmuyor. Düsünüyorlar ki bunların alan bilgisi var. Bunlara pedagojik formasyon verirsek ögretmenlik becerisi de kazanırlar. Yani ögretmen yetisstirmenin en önemli ayaklarından biri olan formasyon becerisinin bu tip bir kursla kazanılabileceği yönünde bir varsayım var. Amacına ulaşıyor mu? Hayır." (Ö1)

"Kesinlikle amacına ulaştığına inanmıyorum. Çünkü çocuklar zaten öğretmen olma amacıyla gelmiyorlar. Bunu bir basamak olarak kullanıp tekrar kendi branşlarına geçmek istiyorlar. Dersler teorik olarak kalıyor, uygulama boyutu olmadığı için amacına kesinlikle ulaşmıyor." (Ö10)

Az sayıda öğretim elemanı ( $\mathrm{n}=3$ ) PFSP'nin amacına ulaştığını düşünmektedir. Bu görüşte olan bir öğretim elemanı şunları söylemektedir:

"Bizim üniversitemizde büyük çoğunlukla amacına ulaştığını düşünüyorum. Çünkü gelen arkadaşlar, büyük bir çoğunluğu teşekkür ederek ayrllyyor. Daha önce ögrenmediği bilgileri ögrendiklerini, çok şey öğrendiklerini söyleyerek ayrllıyorlar. ” (Ö4)

Öğretim elemanlarının PFSP'nin gerekliliğine ilişkin görüşleri Tablo 3'de verilmiştir:

Tablo 3. Pedagojik Formasyon Sertifika Programının Gerekliliğine İlişkin Görüşler

\begin{tabular}{|c|c|c|c|}
\hline Tema & $\begin{array}{c}\text { Alt } \\
\text { Tema }\end{array}$ & Kod & $\mathbf{n}$ \\
\hline \multirow{5}{*}{ Gerekliliği } & \multirow{3}{*}{$\begin{array}{l}\text { Gerekli } \\
\text { Değil }\end{array}$} & Eğitim fakültelerinde yeterli öğretmen adayının yetiştiriliyor olması & 7 \\
\hline & & PFSP’nin niteliğinin düşük olması & 5 \\
\hline & & PFSP ile ilgili yapılan araştırmaların olumsuz sonuçları & 2 \\
\hline & \multirow{2}{*}{ Gerekli } & Fen- Edebiyat mezunlarının öğretmen olabilmesi için & 3 \\
\hline & & Bazı branşlarda ögretmen yetiştiren kurum olmaması & 2 \\
\hline
\end{tabular}

Tablo 3'e göre 14 öğretim elemanı PFSP'yi gereksiz bulmaktadır. Tablo 2'de görüldüğü gibi PFSP'nin amacına ulaşmadığını söyleyen öğretim elemanları, bu nedenle programı da gereksiz bulmaktadır. Bu görüşün en önemli gerekçesi ise eğitim fakültelerinin yeterli sayıda öğretmen adayı yetiştiriyor olmasıdır. Diğer görüşler ise PFSP'nin niteliğinin düşük olması ve bu konuda yapılan araştırmaların programın etkili olmadığına ilişkin sonuçlara ulaşmasıdır. Az sayıda öğretim elemanı (n=3) PFSP'yi gerekli bulmaktadır. Öğretim elemanlarının PFSP'nin gerekli/gereksiz olduğuna ilişkin görüşlerinden bazıları şöyledir:

"Bu ülkede eğitim fakültesi varsa formasyon verilmemeli. Fen-edebiyat fakültesinin kuruluş amacı bilimsel araştırma yapmak ve Türkiye'deki bilim adamı ihtiyacını karşılamaktır. Eğer bunu yapamıyorsak kapatılsın. Eğitim fakültesinin kontenjanın yarı yarıya düşürmek yerine, fen-edebiyatlar kapatılsın. Biz işsiz fen-edebiyat fakültesi mezunlarına iş bulma kurumu muyuz? Öğretmenlik bir inanç işidir. Çocuk ĕgitim fakültesine girdiği andan itibaren ben ögretmen olacă̆ım diyor." (Ö1) 
"Tabi ki gerekliliğine inanıyorum. Çünkü özellikle bazı programlarda biliyorsunuz Türkiye'de öğretmen yetiştiren kurum yok. Mesela Türkiye'de Ulaştırma öğretmeni yetiştiren bir okul yok. Ama bununla ilgili bazı meslek liseleri var. Mecburen buraya ögretmen pedagojik formasyon alarak yetişecek. Başka bir yolu yok." (Ö4)

"Gerekliliğine inanmıyorum. Ĕ̈itim fakültelerinin etkililiğini düşürdüğ̈̈ ve haksızlı̆ga neden olduğu için. Eşitsizliğe neden olduğu için karşıyım. Uzunca zamandan beri de görev almadım. Ben karşı oldukça, eğitim bilimleri dersleri bile başkaları tarafindan veriliyor ve nitelik iyice düşüyor." (Ö11)

\subsection{PFSP'de Yaşanan Sorunlar}

Analiz sonuçlarına göre PFSP'de yaşanan sorunlar öğrenme-öğretme süreci, öğrenci, ders içerikleri, değerlendirme, öğretmenlik uygulaması, genel sorunlar ve öğretim elemanı temalarında yoğunlaşmaktadır. Tablo 4'de PFSP'de yaşanan sorunlara ilişkin öğretim elemanı görüşleri yer almaktadır:

Tablo 4. Pedagojik Formasyon Sertifika Programının Sorunlarına İlişkin Görüşler

\begin{tabular}{|c|c|c|c|}
\hline Tema & Kod & $\mathbf{n}$ & Toplam \\
\hline \multirow{10}{*}{$\begin{array}{l}\text { Öğrenme-Ö̆ğretme } \\
\text { Süreci }\end{array}$} & Derslerin geç saatlerde yapılması & 16 & \multirow{10}{*}{80} \\
\hline & Sinıfların kalabalık olması & 13 & \\
\hline & Ağırlıklı olarak anlatım yöntemi kullanılması & 12 & \\
\hline & Derslerin blok yapılmasi & 7 & \\
\hline & Ders sürelerinin resmiyetten az yapılmas1 & 7 & \\
\hline & Farklı yöntem-tekniklerin kullanılmaması & 6 & \\
\hline & Etkinlik ve uygulamalara yeterince yer verilmemesi & 6 & \\
\hline & Materyal kullanımının yeterli düzeyde olmaması & 6 & \\
\hline & Fiziksel koşulların yeterli olmaması & 4 & \\
\hline & Öğrencilerin yeterince aktif kılınamaması & 3 & \\
\hline \multirow{11}{*}{ Öğrenciler } & Diploma/belge almaya gelmeleri & 15 & \multirow{11}{*}{79} \\
\hline & İsteksiz olmaları & 10 & \\
\hline & Güdülenme düzeylerinin düşük olması & 9 & \\
\hline & Yorgun olmaları & 9 & \\
\hline & Yoğun olmaları & 7 & \\
\hline & Bilgi alt yapılarının eksik olması & 7 & \\
\hline & Sınıf içi istenmeyen davranışları & 6 & \\
\hline & Derse katılımlarının düşük olması & 5 & \\
\hline & Ulaşım problemleri & 4 & \\
\hline & Devamsizlık & 4 & \\
\hline & Öğrenci seçim kriterlerinin yetersiz/yanlıș olmas1 & 3 & \\
\hline \multirow{8}{*}{ Ders İçerikleri } & Derslerin uygulama saatlerinin azlığ 1 & 11 & \multirow{8}{*}{65} \\
\hline & Programın yoğunlaştırılmış olması & 11 & \\
\hline & Derslerin bağlantılı ve uygun sırayla verilmemesi & 10 & \\
\hline & Kuramsal bilgi ağırlıklı & 10 & \\
\hline & Programın süresinin kısa olması & 7 & \\
\hline & Ders içeriklerinin daraltılması & 6 & \\
\hline & Ders saatlerinin yeterli olmamas 1 & 5 & \\
\hline & Zorunlu-seçmeli derslerin uygunsuz seçimi & 5 & \\
\hline \multirow{5}{*}{ Değerlendirme } & Ağırlıklı olarak çoktan seçmeli testlerin kullanılması & 12 & \multirow{5}{*}{40} \\
\hline & Performans (proje, sunum, uygulama vb.) & 12 & \\
\hline & değerlendirme yapılamaması & & \\
\hline & Ders içi katılımın değerlendirilmemesi & 10 & \\
\hline & Öğrencilere dönüt verilememesi & 6 & \\
\hline
\end{tabular}


Pedagojik Formasyon Sertifika Programına Yönelik Sorunlar ve Çözüm Önerileri: Öğretim Elemanlarının Bakış Açıısı

Tablo 4. (devam1)

\begin{tabular}{|c|c|c|c|}
\hline Tema & Kod & $\mathbf{n}$ & Toplam \\
\hline \multirow{6}{*}{$\begin{array}{l}\text { Öğretmenlik } \\
\text { Uygulamasıyla } \\
\text { İgili Sorunlar }\end{array}$} & Sürenin yetersiz olması & 7 & \multirow{6}{*}{27} \\
\hline & Bir danışmanda çok sayıda öğrenci olması & 6 & \\
\hline & Eğitim fakültesindeki verimlilikte olmaması & 4 & \\
\hline & Bir sınıfta çok sayıda öğretmen adayı olması & 4 & \\
\hline & Öğrencilerin lisans dersleriyle çakışması & 3 & \\
\hline & Danışmanların ciddiye almıyor olması & 3 & \\
\hline \multirow{5}{*}{$\begin{array}{l}\text { Genel/Diğer } \\
\text { Sorunlar }\end{array}$} & Kaydolan bütün öğrencilerin formasyon belgesini alması & 7 & \multirow{5}{*}{19} \\
\hline & Öğretmenlik mesleğinin değerini düşürmesi & & \\
\hline & Politika/yönetmeliğin sık değişmesi & 6 & \\
\hline & Öğretim üyesi yetersizliği olan üniversitelerin öğrenci & 3 & \\
\hline & kontenjanlarının çok olması & 3 & \\
\hline \multirow{3}{*}{$\begin{array}{l}\text { Öğretim Üyeleri } \\
\text { ile İlgili Sorunlar }\end{array}$} & $\begin{array}{l}\text { Öğretim elemanlarının derslere ekonomik nedenlerle } \\
\text { girmesi }\end{array}$ & 4 & \multirow[t]{2}{*}{7} \\
\hline & Derslere ilgisiz (alan dışı) öğretim üyelerinin girmesi & 3 & \\
\hline & Genel Toplam & & 317 \\
\hline
\end{tabular}

\section{Öğrenme-Öğretme Süreci}

Öğretim elemanları en fazla derslerin öğrenme-öğretme süreci temasında sorun bildirmiştir. Derslerin geç saatlerde, kalabalık sınıflarda ve anlatım ağırlıklı işlenmesi öğretim elemanlarının en fazla üzerinde durdukları sorunlardır. Öğretim elemanları görüşmelerde akşam ve en az 5060 kişilik sınıflarda ders yaptıklarını belirtmiştir. Bazı görüşler şu şekildedir:

"Dersler akşsam saatleri olduğu için ögrrencilerin ilgisi az ve yorgunlar. Kalabalık sınıflar, 80 kişiden aşağl olmuyor sinuflar. Bir tek ögretim teknolojileri ve materyal geliştirme sinıfi 20 kişiydi onlar verimli oldu. O grupta uygulama yapabildik. Ögrenciler aktif olabiliyor." (Ö3)

"Normalde her hocada olduğu gibi anlatım tekniğini kullaniyorum. Zaten programın sıkıştırılmış olması sinırlyyor. Bizim daha çok geleneksel diye düşündü̈̆ümüz yöntemleri kullaniyorum. Derslerin niteliği uygulamaya uygun değil. Dolayısılla yapamıyoruz.” (Ö9)

Ayrıca derslerin blok yapılmasının sorunlara yol açtığı, derslerin zamanından erken bitirildiği, farklı yöntem-teknik, etkinlik ve uygulamaların yapılamadığı, materyal kullanımının yetersiz olduğu ve öğrencilerin derslere aktif katılamadığ1 görülmektedir. Ö12 ve Ö6 görüşlerini şu şekilde ifade etmektedir:

"Sinıfin mevcuduna ve dersin özelliğine göre yöntem kullaniyoruz. Mesela sinıf mevcudu elverişliyse grup çalışmaları da yaptırlyoruz. Uygulamalı etkinlikler de yaptırıyoruz. Ama çok kalabalıksa yaptıramayabiliyoruz. Zaten her dersin süresi çok sınırlı.”(Ö12)

"Yani zaten bizim derslerimizin hepsi teorik. Uygulamalı ders yok. Bazen eğitim tarihinde bazı kişilerin konusuna ilişkin, bazı düşünürleri ödev olarak veriyorum. Onlarla ilgili öğrenciler çalışmalarını sunabiliyorlar." (Ö16)

\section{Öğrenci Sorunları}

Öğrenme-öğretme sürecinden sonra en fazla sorun bildirilen tema öğrencilerle ilgilidir. Tabloya göre öğrencilerde en fazla rastlanan sorun, programa öğretmen olmaktan çok bir diploma/sertifika almak için gelmeleridir. Diğer sorunlar öğrencilerin eğitime istek duymamaları, güdülenme düzeylerinin düşük olması, derslerin akşam saatlerinde olmasından 
dolayı yorgun olmaları, öğrenci olanların gündüz kendi fakültesinde derslerinin olması ya da mezunların bazılarının çalışması nedeni ile yoğun olmaları, derse katılımlarının az olması, bilgi alt yapılarının eksik olması, ücret verdiğini düşünerek devamsızlık yapması ve programa alınan öğrenci seçim kriterlerinin yetersiz olmasıdır. Öğretim elemanlarının bazılarının görüşleri aşağıda verilmiştir:

"Asıl sorun bu ögrrencilerin fakülteye giriş puanları. Şöyle bir örnek vereyim size Gazi üniversitesi fizik bölümüne fizikten 3 tane doğrusu olan ögrenci giriyor fen edebiyattan mezun oluyor. Gazi eğitim fakültesi fizik bölümüne fizikten 20'nin üzerinde doğrusu olan giriyor. Biz bunları formasyon alırken eşitliyoruz. Girdinin kalitesi düşük. "(Ö2)

"Öğrencilerin bu sertifikayı bir belge olarak düşünmesi bu sürece karşı çok olumlu bir düşünceleri olmadığını gösteriyor. Sertifika almak için geliyorlar, o eğitimin gerekliliğine inanmiyorlar." (Ö17)

\section{İçerik}

PFSP derslerinin içeriği ile ilgili yaşanan en temel sorunlar derslerin uygulama saatlerinin azlığı, programın süresinin kısa olması, birbirinin önkoşulu derslerin uygun sırada verilmemesi ve kuramsal ağırlıklı yürütülmesidir. Öğretim elemanlarına göre ders içerikleri ile ilgili diğer yaşanan sorunlar ders saati azlığı nedeniyle içeriklerin daraltılması ve zorunlu ve seçmeli derslerin uygun seçilememesidir. Pedagojik formasyon kapsamındaki dersler eğitim fakültelerinde öğretmenlik meslek bilgisi kapsamında sekiz yarı yıla dağıtılarak verilmektedir. Derslerin kısa bir süre içinde verilmesi zorunluluğu, öğretim elemanlarının da belirttiği gibi pek çok sorunu beraberinde getirmektedir. Bazı öğretim elemanı görüşleri şu şekildedir:

"Şu anda uygulanan sıkıştırılmış bir program. 14 haftayı 3.5 aya sikıştırıyor. 4 saatlik bir dersi bir haftada 8 saat olarak allyor ögrenci. 8 saat bir haftada çok yoğun bir ögrenci için. Bu süre açısından çok sikıntılı bir durum. Bir dersten diğerine giriyor öğrenci. Bir de bu derslerin sıralaması var. Öğretmenlik mesleğine girişle aynı anda ölçme değerlendirme alması kadar saçma bir şey olamaz." (Ö7)

"Dersler önkoşula hiç uymuyor. Öğrenci eğitim bilimlerine girişi de aynı dönemde altyor rehberliği de aynı dönemde alıyor. Seçmeli olursa ögrenci bazen gelişim psikolojisini almıyor." (Ö9)

\section{Ölçme-Değerlendirme}

PFSP derslerinde değerlendirme boyutunda yaşanan sorunlar ağırlıklı olarak çoktan seçmeli testlerin kullanılması, öğrencilerin performanslarının değerlendirilmemesi, ders katılımlarının değerlendirmeye katılmaması ile öğrencilere performansları ile ilgili dönüt verilememesidir. Öğrenciler ile ilgili sorunlarda belirtildiği üzere, PFSP sınıflarının kalabalık olması öğretim elemanlarının alternatif ölçme-değerlendirme yöntemlerini kullanmalarını engellemektedir. Öğretim elemanı görüşlerinden bazıları aşağıda verilmiştir:

"Ama dediğim gibi kalabalık sinıflarda dönüt vermek çok zor oluyor. O nedenle kalabalık sınıflarda öyle birebir çok da gönlümden geçen bir ödev ve değerlendirme yaptığımı söyleyemem." (Ö3)

"Bir projeyi verip sınf geçme ya da final notu falan deyip insanlar kendi kendilerini kandırlyorlar. Sınav yapmamak için, yani bilinçli gerçekten ögrencinin başarısını ölçebilecek ödev ve proje verip de değerlendirme yapıldığını düşünmüyorum. Özel öğretim yöntemi 
Pedagojik Formasyon Sertifika Programına Yönelik Sorunlar ve Çözüm Önerileri: Öğretim Elemanlarının Bakış Açıısı

dersinde 60 kişilik sınıfa 2 saatlik derste hem yöntemleri hem de o alanla ilgili uygulama mı yaptıracaksınız." (Ö7)

\section{Öğretmenlik Uygulaması}

Öğretim elemanlarından yedi tanesi PFSP'de Öğretmenlik Uygulaması dersine girmiştir. Buna göre uygulamalarda yaşanan en önemli sorun sürenin yetersiz olmasıdır. Bunun dışında bir danışman üzerindeki öğrenci sayısının çokluğu, eğitim fakültesindeki verimlilikte yürütülememesi, uygulamaların öğrencilerin kendi fakültelerindeki lisans dersleri ile çakışması ve danışmanların bu işi ciddiye almamaları gibi sorunlar dile getirilmiştir. Öğretim elemanlarından bazılarının görüşleri şu şekildedir:

"Normalde 7 hafta diye geçiyor. Ama ögrrencilerin bir kısmı çalıştıkları için gidemiyorlar. Ama yine de uygulama yapmalarını, okula gitmelerini istiyorum yani"(Ö1)

"Yedi haftaya sıkıştırılmış, aşağı yukarı adet yerini bulsun diye yapılan bir uygulamayla ögretmen olunmayacağını hepimiz biliyoruz. Ama burada ekonomik kaygılar maalesef bizim gibi söylemde bu iş olmaz diyen hocaları da sinıfta ders verir hale getiriyor. Bu da üniversite hocalarının duruşundaki problemlerin göstergesidir. " (Ö5)

\section{Genel Sorunlar}

PFSP'de yaşanan genel sorunlar öğretim elemanlarınca şöyle belirtilmiştir: PFSP'ye kayıt yaptıran her öğrencinin diploma alacağı beklentisi, programın öğretmenlik mesleğini bir sertifikaya indirgeyerek değerini düşürmesi, politika/yönetmeliklerin sık değişmesi, öğretim üyesi yetersiz olduğu halde bazı üniversitelerdeki öğrenci sayısının fazla olmasıdır. Öğretim üyelerinden bazılarının görüşleri aşă̆ıda verilmiştir:

"Öğrenci formasyon derslerine kayıt olurken sonunda diplomayı alacağını garanti olarak görüyor. Bu da derslere asılma davranışını engelliyor. Yani ögrenci bir şekilde geldiği zaman geçip bitireceğini düşünüyor. Formasyonun başlayıp biten bir süreç olduğu ve zaten diplomayı vermek zorunda olduklarl yönünde bir algı var." (Ö1)

"Formasyon programinın kendisi sorun. Bunu buradaki ögretim üyelerinin hepsinin söylemesi lazım ama para kazandıkları için söylemiyorlar. Normal şartlarda hiçbir özellikle eğitim bilimlerindeki akademisyenlerin bu iyidir demesi kendini inkâr etmesinden başka bir şey demek değildir." (Ö7)

"Bir de bir politika birlikteliği yok. Böyle bir eğitimde kararlar öyle hızlı değişiyor ki. En son alınan karar. Kontenjanlarda belirli bir kısitlamaya gidileceği. Yaklaşık 400 bine yakın formasyon belgesi olan ve atanmayı bekleyen ögretmen adayı olduğu düşüncesi ifade edildikten sonra, bir kaç gün sonra kontenjanların yeniden serbest birakıldığını görebiliyoruz. Dolayısıyla bir politika birlikteliği olmayınca bu olayın ciddiyetini bozuyor." (Ö13)

\section{Öğretim Elemanı}

En az sorun bildirilen tema öğretim elemanı teması olmuştur. Öğretim üyelerinin bu konuda bildirdiği iki sorun bulunmaktadır: Öğretim üyelerinin derslere ekonomik nedenlerle ve alan dışından girmesidir. Öğretim üyelerinin PFSP'yi para kazanma kaynağı olarak görmelerinin ve kendi fakültelerinde vermedikleri dersleri PFSP'de vermelerinin, eğitimin niteliğini ciddi biçimde azaltacağı açıktır. Ö5 görüşlerini şu şekilde ifade etmiştir: 
"Formasyondaki temel kaoslardan biri de tüm dersleri herkesin anlatabileceğine dair bir yargl ve yanılgı var. Böyle bir şeyi farkl gruplarda farklı toplumlarda söyleseniz herkes size güler. Yani 10 yll 15 yll bu işte çaba sarf etmiş insanın karşısına bu konuya dair bir cümle kurmayan adamlar da, ücret politikalarından dolayı rakip ögretim üyesi olarak çıkabiliyor." (Ö5)

\subsection{PFSP'nin Niteliğini Artırmaya Yönelik Öneriler}

Öğretim elemanlarına son olarak PFSP'de yaşanan sorunlara yönelik önerilerinin neler olduğu sorulmuştur. Öğretim üyelerinin önerilerinin öğrenme-öğretme süreci, PFSP'nin yapıs1, öğrenci, derslerin içeriği, öğretmenlik uygulaması ve öğretim elemanı boyutlarında yoğunlaştığı görülmektedir. Öğretim elemanı görüşlerine Tablo 5'de yer verilmiştir:

Tablo 5. Pedagojik Formasyon Sertifika Programında Yaşanan Sorunlara Yönelik Öneriler

\begin{tabular}{|c|c|c|c|}
\hline Tema & Kod & $\mathbf{n}$ & Toplam \\
\hline \multirow{9}{*}{$\begin{array}{l}\text { Öğrenme- } \\
\text { Öğrretme Süreci }\end{array}$} & Uygulamalı ders saatleri arttırılmalı & 13 & \multirow{9}{*}{62} \\
\hline & Dersler erken saatlerde yapılmalı & 11 & \\
\hline & Sınıflar alanlara göre ayrılmalı & 9 & \\
\hline & Fiziksel koşullar iyileştirilmeli & 7 & \\
\hline & Dersler blok yapılmamalı & 7 & \\
\hline & Öğrenci dersten kalabilmeli & 6 & \\
\hline & Dersler hafta sonu yapılmalı & 4 & \\
\hline & Değerlendirme, merkezi bir yeterlilik sınavıyla yapılmalı & 3 & \\
\hline & Devam zorunluluğu olmamalı & 2 & \\
\hline \multirow{5}{*}{$\begin{array}{l}\text { PFS } \\
\text { Programının } \\
\text { Yapısı }\end{array}$} & Programın süresi uzatılmalı/yayılmalı & 17 & \multirow{5}{*}{36} \\
\hline & Formasyon verilmemeli & 7 & \\
\hline & Program lisansla paralel yürütülmeli & 4 & \\
\hline & Kontenjanlar üniversitelere eşit dağıtılmamalı & 4 & \\
\hline & İstikrarlı politikalar olmalı & 4 & \\
\hline \multirow{6}{*}{ Öğrenciler } & Öğrencilerin ciddiyeti arttırılmalı & 8 & \multirow{6}{*}{36} \\
\hline & Öğrencilerin güdülenme düzeyleri arttırılmalı & 8 & \\
\hline & Nitelikli öğrenciler seçilmeli & 7 & \\
\hline & Mezun-lisans öğrenci grupları ayrılmalı & 5 & \\
\hline & Öğrencilerin ilgi ve yetenekleri iyi anlaşılmalı & 5 & \\
\hline & Öğrencilerin ulaşım imkânları düşünülmeli & 3 & \\
\hline \multirow{4}{*}{ Derslerin İçeriği } & Dersler ön koşul olma durumuna göre sıralanmalı & 13 & \multirow{4}{*}{30} \\
\hline & Ders içerikleri düzenlenmeli & 8 & \\
\hline & Programda zorunlu-seçmeli ders dengesine dikkat edilmeli & 6 & \\
\hline & Ders sayısı arttırılmalı & 3 & \\
\hline \multirow{3}{*}{$\begin{array}{l}\text { Öğretmenlik } \\
\text { Uygulaması }\end{array}$} & Süresi arttırılmalı & 8 & \multirow{3}{*}{20} \\
\hline & Ciddiyeti arttırılmalı & 7 & \\
\hline & Gruplarda daha az öğrenci olmalı & 5 & \\
\hline \multirow{4}{*}{$\begin{array}{l}\text { Öğretim } \\
\text { Elemanları }\end{array}$} & Dersleri alanında uzman öğretim üyeleri vermeli & 5 & \multirow{3}{*}{7} \\
\hline & Öğretim üyeleri istekli olmalı & 1 & \\
\hline & Öğretim üyeleri sabırlı olmalı & 1 & \\
\hline & Genel Toplam & & 191 \\
\hline
\end{tabular}

\section{Öğrenme-Öğretme Sürecine İlişkin Öneriler}

Öğretim üyelerinin önerilerinin sorunlar da olduğu gibi, en fazla bu tema altında toplandığı görülmektedir. $\mathrm{Bu}$ tema altında dokuz öneri yer almaktadır. En fazla yapılan öneriler, uygulamalı ders saatlerinin arttırılması, derslerin akşam saatleri yerine daha erken saatlerde yapılması ve sınıfların karma değil alanlara göre oluşturulması yönündedir. Görüldüğü gibi öğretim elemanları PFSP'nin öğrenme-öğretme sürecinde yaşanan sorunlar paralelinde çözüm önerileri getirmiştir. Buna göre ders saatlerinin ve özellikle uygulamaların artırılması, derslerin 
Pedagojik Formasyon Sertifika Programına Yönelik Sorunlar ve Çözüm Önerileri: Öğretim Elemanlarının Bakış Açısı

akşam saatlerinde olmasından vazgeçilmesi, fiziki ortamların iyileştirilmesi, öğrencilerin programa devamlarının sağlanması gerekmektedir. Bazı öğretim elemanlarının görüşleri şu şekildedir:

"Bir de şey var tabii branşlara göre de mesela öğretim ilke ve yöntemlerinin girilen sinıfin yapısına göre de uyarlanması gerekiyor. Kimya mı, edebiyat mı, Ingilizce mi nedir alanları işte bu bölümlere göre en çok hangi yöntemlere gerek olabilir hangi yöntemler daha etkili olabilir." (Ö2)

"Derslerin veriliş sırası da sorun. Bazı ön koşul olan dersler var mesela. Bunların öncelikli alınmış olması gerekiyor. Bu anlamda programda seçmeli zorunlu derslerle birlikte derslerin verilişs strası da yeniden düzenlenmeli." (Ö13)

"14 hafta az. Öğretmen yetiştirmek için ders saati az. Programın süresi yayllmall, ders saatleri arttırılmall, uygulama yapılabilmeli, dersler daha erken saate alınmalı." (Ö17).

Dersliklerin fiziksel koşullarının iyileştirilmesi ve iki ders saati biçiminde blok yapılmaması diğer dikkat çeken önerilerdir. Öğretim elemanlarından bazıları, öğrencinin dersten kalabilmesi ile ilgili önemli bir konuya değinmiştir. Öğrencinin dersten geçmesi için bir zorunluluk bulunmamakla birlikte, öğretim üyeleri öğrencilerin bu yönde bir beklentilerinin olduğunu ve "para veriyoruz, geçmeliyiz" diye düşündüklerini belirtmektedir. Az da olsa PFSP sonunda değerlendirmenin merkezi yapılması ve devam zorunluluğunun kaldırılması gerektiğini düşünen öğretim elemanları bulunmaktadır. Ö10 görüşlerini şu şekilde dile getirmektedir:

"Benim gerçek ögrencim ben bir ögretmen olacağım diye geliyor ve ögretim elemanı, okulun ilkelerine dikkat ediyor. Fakat formasyon ögrencisinden de bu yönde davranışlar beklediğiniz zaman Bir para verdikleri için çok ciddiye almiyorlar. Para verdik, geçmeliyiz diye düşünüyorlar. Motivasyon genel anlamda hiç yok. Bazı ögrenciler istisna olabilir.” (Ö10)

\section{PFSP'nin Yapısına İlişskin Öneriler}

Öğretim elemanlarının tamamı PFSP'nin süresinin daha uzun olması gerektiğini ve daha uzun bir sürece yayılması gerektiğini düşünmektedir. Öğretim elemanlarının görüşlerinden bazı alıntılar aşağıda sunulmuştur:

"O işin içine girebilmeleri için uygulamalı ortamlar gerekli. Diyelim ki formasyona gerçekten ihtiyaç var. Öyle bir durumda bile en az iki yıla yayılarak işte tezsiz yüksek lisans da olabilir ya da başka bir formda da olabilir." (Ö2)

"Hızlandirıyorsun. Niye? KPSS sınavina yetişsin diye. Bunlardan vazgeçmek gereklidir. Önce ilkeleri bir ortaya koyup bu ilkelerde tutarl davranmak gerekiyor. 14 hafta sürecekse 14 haftadir. Yok KPSS'ye yetişti, yetişmedi filan gibi şey yok." (Ö12)

Yedi öğretim elemanı PFSP'nin kaldırılması gerektiğini düşünmektedir. Öğretim elemanlarının PFSP'de hem görev almaları hem de kaldırılması gerektiğini söylemeleri üzerinde düşünülmesi gereken bir konudur. Bu sonuca göre, programın etkililiğini ciddi biçimde sorgulamak gerekmektedir.Öğretim elemanlarının görüşlerinden bazı alıntılar aşağıda sunulmuştur:

"Çözüm önerim tümünü kapsayıcı olacak formasyon programı ile ilgili ama öncelikle olmamasından yanayım. Yani dertlerin tümünü ortadan kaldırabilmek için bu işin olmaması. Olacaksa da niteliğinin biraz daha arttırılmasına yönelik çabalar lazım diye düşünüyorum. Yani 
biraz daha fazla ders olabilir. Biraz daha uzun soluklu bir program olabilir. Uygulama boyutu daha uzun soluklu bir işi gerektiriyor."(Ö6)

"Formasyon kesinlikle kaldırllmalı. Ë̆itim fakültesindeki ögrenci dışardan ders alarak doktor ya da mühendis olamadı̆̆ gibi diğerleri de öğretmen olamamalı." (Ö11).

Bazı öğretim elemanları programın devam etmesini ve hatta lisans sırasında verilmesini önerirken, bazıları ise fakültelerin öğretim elemanı sayısı dikkate alınmadan planlama yapıldığını ve her üniversiteye aynı sayıda PF öğrencisi kontenjanı ayrıldığını, bunun yerine öğrenci sayılarının fakültelerin öğretim üyesi sayısı dikkate alınarak belirlenmesini önerilmektedir. Öğretim elemanlarının görüşlerinden bazı alıntılar aşağıda sunulmuş̧tur:

"Merkez üniversitelerin bunu iyi yaptığını düşünüyorum. Taşra üniversiteleri olaya tamamen paragözüyle bakıyorlar. Bu yüzden de istendik faydanın oluştuğunu düşünmüyorum. Her

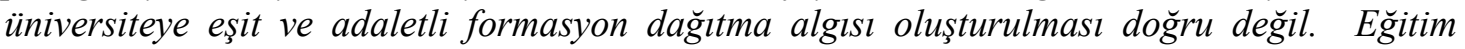
fakültesinde iki tane yrd.doç. ile çılıp da formasyon vermek, evet onlara iki üç kuruş para kazandırabilir. Ama eğitim sisteminin ihtiyacı olan insan gücünü yetiştirmede gerekli koşulu sağlamıyor. Yani bunu verebilecek üniversitelerin saptanması lazım, yani bu yeterliliğe haiz."(Ö16)

\section{Öğrencilerle İlgili Öneriler}

Öğretim üyelerinin öğrenci niteliğine ilişkin en önemli önerileri; öğrencilerin PFSP'ye yönelik ciddiyetlerinin ve güdülenme düzeylerinin arttırılması, daha nitelikli öğrencilerin programa kabul edilmesi, mezun-lisans öğrencilerin farklı gruplarda yer alması, öğrencilerin ilgi ve yeteneklerinin dikkate alınması yönündedir. Bazı öğretim elemanları da $(n=3)$ öğrencilerin ulaşım olanaklarının dikkate alınması gerektiğini düşünmektedir. Öğretim elemanlarının bazılarının görüşleri şu şekildedir:

"Her bireyin kendi alanında master yapması gerek. Yani fizikçiyse kendi alanında yüksek lisans yapsın. Yüksek lisanslı ögrenci gelsin. Önce iyice alanı ile bütünleşmesi lazım. Alanı ile iyice bütünleşmiş bireye formasyon dersi verilmesi lazım. Lisansını bitiren herkesin ögretmen olmak için formasyon almasını doğru bulmuyorum." (Ö1)

"Ama öyle çok büyük bir eksiklik görmüyorum. Yöntem açısından baklyorum. Öğrenci istekli olduğu sürece her şey olur. L̇yi bir ögretmen olma amacının farkında olan herkese biz de elimizden gelen her şekilde yardımcı oluruz." (Ö9)

\section{Dersin İçeriği İle İlgili Öneriler}

Derslerin PFSP'ye yerleştirilirken önkoşul olma ilişkilerine dikkat edilmesi, ders içeriklerinin yeniden düzenlenmesi, programda zorunlu-seçmeli ders dengesinin olması ve ders sayısının daha fazla olması öğretim elemanlarınca en fazla dile getirilen önerilerdir. Ö4 bu konuda görüşlerini şu şekilde ifade etmektedir:

"Dersler değişiyor sürekli. Tabi değişecek ama bazı dersler temeldir. Zorunlu olmalı ve belli bir saatin üzerinde olmalı. Mesela eğitim psikolojisi bir önceki yönetmelikte seçmeliydi sonra zorunlu oldu. Gelişim psikolojisi ikisinde de seçmeli. Rehberlik bir öncekinde zorunluydu şimdi seçmeli oldu. Derslerin zorunlu-seçmeli olma ve ön koşul olma durumları ile ilgili uygulayıcılardan görüs alınması gerekiyor." (Ö4) 
Pedagojik Formasyon Sertifika Programına Yönelik Sorunlar ve Çözüm Önerileri: Öğretim Elemanlarının Bakış Açısı

\section{Öğretmenlik Uygulamasıyla İlgili Öneriler}

Öğretim üyeleri öğretmenlik uygulamalarına ayrılan sürenin yetersiz olduğunu ve öğrencilerin öğretmenlik uygulamalarını çok fazla ciddiye almadıklarını düşünmektedir. Onlara göre öncelikle bu sorunların üstesinden gelinmeli, daha sonra gruplardaki öğrenci sayıları azaltılmalıdır. Görüşlerden bazıları şu şekildedir:

“Öğretmenlik uygulamaları bence öğrenciler tarafindan da ögretim elemanları tarafindan da yeterince ciddiye alınmıyor. Bunun ciddiyetinin fark ettirilmesi adina bir şeyler yapllmall. Mesela saatleri arttırllip ögrenci sayıları mümkün mertebe azaltılabilir. " (Ö11)

"Öğretmenlik uygulaması ile ilgili de bazı düzenlemeler yapılmall. Bir kere bu süre çok yetersiz. Her bir öğrenciyi değerlendirebileceğimiz daha uzun süreli bir uygulama süreci olmall.” (Ö14)

\section{Öğretim Elemanları İle İlgili Öneriler}

En az öneri öğretim üyeleri teması altında olmuştur. Öğretim üyeleri ile ilgili öneriler ise, derslere alan uzmanlarının girmesi, öğretim üyelerinin ders vermede istekli olması gerektiği şeklindedir. Bu konuda Ö5'in görüşü şöyledir:

"Dersleri veren akademisyenin de rolü önemli. Öğrencileri motive hale getirmek için öncelikle hocanın istekli olması gerekiyor. Bazı hocalar bu noktada dersi vermede isteksiz. Olaya maddi bir gelir kapısı olarak bakanlar da var. Bu noktada hem yeterli hem istekli akademisyenleri işe koşmak gerek." (Ö5)

\section{Tartışma ve Sonuçlar}

Öğretim elemanlarına göre PFSP'nin temel amacının nitelikli öğretmen yetiştirmek olması gerektiği, ancak programın bu amaca ulaşamadığı ve öğretmen niteliklerinin kazandırılamadığı anlaşılmaktadır. Öğretim elemanları PFSP'nin uygulamadaki temel amacının, fen-edebiyat mezunlarına öğretmenlik sertifikası vererek iş bulmalarını kolaylaştırmak olduğunu düşünmektedir. PFSP ekonomik kaygılarla yani üniversite ve öğretim elemanlarına para kazandırmak için açılmaktadır. Yılmaz'ın (2015) çalışmasında da öğretim elemanlarının çoğu PFSP'nin yanlış ve gereksiz bir uygulama olduğunu ve kısa sürede öğretmen yeterliklerini kazandırmanın mümkün olmadığını düşündükleri bulgulanmıştır. Durmuşçelebi’nin (2015), Dündar ve Karaca'nın (2013), İncik ve Akay'ın (2014) ve Yapıcı ve Yapıcı'nın (2013) çalışmalarında da ögrencilerin PFS eğitimini yararsız ve gereksiz gördüğü bulunmuştur.

Araştırmaya katılan öğretim elemanlarının çoğu PFSP'de derse girmesine rağmen, programı gereksiz görmektedir. Öğretim elemanlarının programı gereksiz bulup, ders vermesi ilginç bulunmuştur. Bir işin gerekliliğine inanmayan bireylerin, o işin başarılı olması için çabalayacaklarını düşünmek uzak bir olasılıktır. Başka çalışmalarda da PFS eğitimi veren öğretim üyelerinin çoğunluğu, programla ilgili olumsuz görüşlere sahiptir (Atmaca, 2019; Köse, 2017; Yılmaz, 2015). Gönülaçar (2016), fen-edebiyat fakültesi dişında diğer fakültelere de (İlahiyat, güzel sanatlar, iletişim, spor eğitimi) pedagojik formasyon hakkı tanındığı düşünüldüğünde, öğretmen yetiştiren tüm kurumlarda 734.000 öğrenci olduğunu, gelecek 4 yıl içinde (yani 2020) sistemin 734.000 öğretmen adayı ile karşı karşıya kalacağını söylemektedir. Bu nicel artışın yanında PFSP'larının nitelikli öğretmen yetiştirememesi, gerekliliğini daha da sorgular duruma getirmektedir. 
PFSP'de yaşanan sorunlara ilişkin şu sonuçlara ulaşılmıştır. Öğretim elemanlarının PFSP'ye ilişkin görüşleri incelendiğinde, en önemli sorunun derslerin öğrenme-öğretme süreci ile ilgili olduğu görülmektedir $(n=80)$. En fazla belirtilen sorunlar derslerin akşam üzeri geç saatlerde kalabalık sınıflarla yapılmasıdır. Kalabalık sınıflar doğal olarak öğrencilerin derse katılımını azaltmakta, bir diğer önemli sorun olan dersin anlatım ağırlıklı işlenmesine yol açmaktadır. Zaten süresi az olan derslerin zamanından önce bitirilmesi, uygulamaların sınırl, materyal kullanımının yeterli olmaması gibi sorunlar, nitelikli öğretmen eğitiminin önündeki ciddi engellerdir. Diğer çalışmalarda da PFS eğitimi alan öğretmen adayları geç saatlerdeki derslerin (Filiz \& Durnali, 2019; Yılmaz, 2015), uygulamaya yer verilmemesinin, programın kisa sürmesinin (Aykaç, Bilgin \& Toraman, 2015; Demirtaş \& Kırbaç, 2016), ağırlıklı olarak kullanılan anlatım yönteminin (Gülhan, 2020) ve aşırı kalabalık sınıfların (Doğanay vd., 2015) öğretmenliğe hazırlanmak için yeterli olmadığını düşünmektedir.

PFSP'ye ilişkin olarak öğretim elemanları öğrencilerle ilgili sorunlara da değinmiştir ( $n=79)$. Öğretim elemanlarına göre bu temadaki en önemli sorun öğretmen adaylarının öğretmenlik için gerekli bilgi ve becerileri kazanmaya değil, iş bulma umudu ile programa devam etmeleridir. Daha az sayıda öğretim elemanı tarafından belirtilmekle birlikte önemli bir sorun da, PFSP'ye seçilecek öğrencilerin niteliğidir. YÖK'ün öğrenci seçim kriterlerini üniversite senatolarına bırakması, üniversitelerin farklı kriterler uygulamasına yol açmıştır. Bu durum ise daha düşük puanlarla fen-edebiyat fakültelerine kabul edilen öğrencilerin (Köse, 2017; Tanrıkulu, 2017), farklı kriterler ile PFSP'ye katılabilmesine ve öğretmen olabilmesine yol açmaktadır. Gürol ve diğerleri (2018), Köse (2007), Memduhoğlu ve Topsakal (2008) ve Yılmaz'ın (2015) araştırmalarında da benzer biçimde ögretim elemanları, PFSP'deki öğrencilerin yeterli istek ve motivasyona sahip olmadığını düşünmektedir.

PFSP'de yer alan derslerin içeriği ile ilgili sorunlar olduğu da görülmektedir. En önemlileri derslerin uygulama saatlerinin çok az olması ve sıkışık, yoğunlaştırılmış bir program uygulanmasıdır. Bunların yanında derslerin uygun sırada yer almaması, kuramsal ağırlıklı yapılandırılması, içeriklerin azaltılması gibi sorunlar da sıklıkla dile getirilmiştir. Eğitim fakültesinde dört yıla yayarak yürütülen dersler, PFSP'de iki dönemde verilmeye çalışılmaktadır. Bu uygulamanın en önemli sakıncası, birbirinin önkoşulu olan derslerin aynı dönemde yer almasıdır. Örneğin öğrenciler ikinci yarıyılda Öğretmenlik Uygulaması ile birlikte, bu ders için önkoşul olan Öğretim Teknolojileri ve Materyal Geliştirme ve Özel Öğretim Yöntemleri derslerini de almaktadır. Literatürdeki diğer çalışmalarda da PFSP derslerinin içeriklerinin ilgi çekici olmadığı, programın süresinin kısa olduğu (Atmaca, 2019; Filiz \& Durnali, 2019; Köse, 2017; Yılmaz, 2015), kuramsal ağırlıklı işlenmesi nedeni ile öğretmen adaylarının bilgileri günlük yaşamla ilişkilendiremedikleri, önkoşul ilişkisi olan derslerin aynı dönemde verildiği sonuçlarına ulaşılmıştır (Doğanay vd., 2015; Filiz \& Durnali, 2019; Gülhan, 2020; Yüksel, 2011).

Öğretim elemanlarına göre PFSP'de ölçme-değerlendirme ile ilgili yaşanan en önemli sorunlar ağırlıklı olarak çoktan seçmeli testlerin kullanılması ve alternatif ölçme-değerlendirme tekniklerine yer verilmemesidir. Öğrencilerin performanslarının ve derse katılımlarının değerlendirilmemesi öğretim elemanlarına göre önemli sorunlardır. PFSP'de yaşanan sorunlardan biri de öğretmenlik uygulamaları ile ilgilidir. Öğretmenlik uygulaması süresinin az olması, uygulama öğretim elemanı üzerinde çok sayıda öğrenci olması, öğretmenlik uygulamalarının eğitim fakültesinde yapıldığı gibi yürütülememesi, uygulamaların öğrencilerin lisans ders saatleriyle çalışması ve danışmanların bu dersleri ciddiye almaması en çok belirtilen sorunlar olmuştur. Bu sonuçlar, öğretmenlik uygulamasının eğitim fakültesindeki verimlilikte olmadığına işaret etmektedir. Öğretmenlik uygulamasında yaşanan sorunlara ilişkin benzer sonuçlar literatürdeki diğer araştırmalarla da desteklenmektedir (Gürol vd., 2018; Taneri, 2016). PF programının ücretinin yüksek olması, öğrencilerde tüm derslerden geçecekleri ve diplomaya 
Pedagojik Formasyon Sertifika Programına Yönelik Sorunlar ve Çözüm Önerileri: Öğretim Elemanlarının Bakış Açısı

hak kazandıkları beklentisi oluşturmakta, bu da derslere yönelik tutumlarını olumsuz yönde etkilemektedir. Öğretmen eğitimi ile ilgili politikaların sıklıkla değişmesi ve öğretim üyesi yeterli olmayan eğitim fakültelerinde PFSP açılması önemli sorunlar arasındadır. Öğretim elemanlarına göre PFSP, öğretmenlik mesleğinin değerini düşürmektedir.

Az da olsa öğretim üyeleri ile ilgili sorunlar da tespit edilmiştir. Belirtilen sorunlar, öğretim elemanlarının derslere ekonomik nedenlerle girmesi ve alan dışı öğretim üyelerinin dersleri yürütmesidir. Alan uzmanı olmayan öğretim elemanlarının ekonomik kaygılarla PFSP derslerini yürütmesi kabul edilebilir bir durum değildir. Öğretim elemanlarının eğitim fakültesinde vermediği bir dersi PFSP'de yürütmesi, programın niteliğinin azalmasına yol açmaktadır. Diğer çalışmalarda da benzer biçimde PFS eğitimindeki en önemli sorunlar, derslere uzman öğretim elemanlarının girmemesi, akademik kadronun yetersizliği, bazı öğretim elemanlarının dersleri ciddiye almaması, isteksiz davranması, motivasyonunun düşük olması ve oturduğu yerden kalkmadan slaytları okumasıdır (Aykaç vd., 2015; Doğanay vd., 2015; Filiz \& Durnali, 2019; Memduhoğlu \& Topsakal, 2008, Sağlam, 2015; Yüksel, 2011).

Öğretim elemanlarının PFSP'ye yönelik önerileri, derslerin öğrenme-öğretme süreci/ortamı, programın yapısı, öğrenciler, derslerin içeriği, öğretmenlik uygulaması ve öğretim üyeleri temalarında toplanmıştır. Derslerin öğrenme-öğretme süreci ile ilgili en fazla öneri derslerin uygulamalı saatlerinin artırılması ve derslerin akşam geç saatler yerine daha erken saatlere çekilmesidir. Benzer sonuçlara diğer araştırmalarda da rastlanmıştır (Gürol vd., 2018; Memduhoğlu \& Topsakal, 2008; Taneri, 2016). Dikkate değer bir öneri de öğrencilerin dersten kalabilmesidir. Öğrencinin dersten kalması için yönetmelikte bir engel olmamasına rağmen, öğretim elemanları kendilerini bu konuda baskı altında ve rahatsız hissetmektedir.

Programın yapısına yönelik en fazla yapılan öneri programın süresinin uzatılmasıdır. Derslere girdiği halde PFSP'nin olmaması gerektiğini düşünen öğretim elemanları da bulunmaktadır. Diğer öneriler programın lisansla birlikte yürütülmesi ve üniversitelere verilen kontenjanların eşit olması yerine, öğretim üyesi sayısına göre planlanması gerektiğidir. Kiraz ve Dursun (2015), Köse, (2017), Memduhoğlu ve Topsakal (2008), Sağlam (2015), Yapıcı ve Yapıcı (2013), Yılmaz'ın (2015) çalışmasında da PFSP'nin niteliğini artırmak için öne çıkan öneriler programın süresinin uzatılması, derslerin uygulamalarının artırılması ve lisans eğitimi ile birlikte verilmesidir. Öğrencilerle ilgili öneriler, öğrencilerin PFSP'ye yönelik olumlu tutum kazanmalarına ve güdülenme düzeylerinin artırılmasına yoğunlaşmıştır. Ayrıca her öğrenciye PFS eğitimi verilmemesi ve nitelikli öğrencilerin seçilmesi gerektiği de öneriler arasındadır. Memduhoğlu ve Topsakal'ın (2008) çalışmasına katılan öğretim elamanları, PFSP'ye girişte taban puan uygulamasının getirilmesini ve giriş puanının yüksek tutulmasını önermektedir.

Derslerin içeriği ile ilgili olarak, öğretim elemanları derslerin önkoşul olma durumuna göre sıralanmasını ve ders içeriklerinin yeniden düzenlenmesini önermektedir. Ayrıca programda seçmeli-zorunlu ders dengesine dikkat edilmesini ve ders sayısının daha fazla olmasını öneren öğretim elemanları da bulunmaktadır. Öğretim elemanları öğretmenlik uygulamaları ile ilgili olarak süresinin ve ciddiyetinin artırılmasını ve gruplardaki öğrenci sayılarının azaltılmasını önermektedir. Öğretim üyelerinin kendilerine ilişkin önerileri ise, derslerin alan uzmanları tarafından verilmesi ve öğretim üyelerinin ders vermeye istekli olmasıdır.

Sonuç olarak öğretim elemanları PFSP'nin nitelikli öğretmen yetiştirmek amacını yerine getiremediğini ve kaldırılması gerektiğini düşünmektedir. Öğretim elemanlarının çoğu, öğrencilerin PFSP'ye diploma beklentisi ile eğitime katılmasının, öğretim üyelerinin ekonomik kaygılarla ders vermesinin, çok kalabalık sınıflarda, geç saatlerde ve öğrenci katılımı olmadan ders yapılmasının, hem öğrencilerin hem de kendilerinin motivasyonlarını düşürdüğünü ve 
programı olumsuz yönde etkilediğini ifade etmişlerdir. Başka bir deyişle belirtilen sorunlara dayalı olarak, PFSP'de etkili öğretmenlik becerilerini kazandırmak için gerekli eğitim ortamının sağlanamadığı söylenebilir. Literatürde PFSP ile ilgili sorunları ortaya koyan çalışmalarda da benzer bulgular mevcuttur (Doğanay, vd., 2015; İzci, 1999; Saylan, 2013; Sürücü, 1997; Şenel, 1999). Yıldırım ve Vural'ın (2014) belirttiği gibi, öğretmen yetiştirme görevinin eğitim fakültelerinde olması gerekmektedir. Çalışmanın sonunda şu önerilerde bulunulabilir: PFSP'nin niteliğini artırmak ve yaşanan sorunları çözebilmek için öncelikle PFSP'ye bakıș açısının değiştirilmesi gerekmektedir. Öğretim elemanları PSPF'yi para kazanma yollarından birisi olarak, öğrenciler de ücret karşılığından alınan bir belge olarak görmekten vazgeçmelidir. PFSP'de ders verecek öğretim üyelerini belirlerken alan uzmanlıklarının dikkate alınması önerilmektedir. PFSP'nin süresi ve uygulamalı saatleri artırılmalı, kalabalık sınıflar yerine öğrencilerin branşları dikkate alınarak dersler küçük gruplarda yürütülmelidir. Böylece öğrenci merkezli öğretim yöntem-teknikleri ile alternatif ölçme-değerlendirme araçlarını kullanma olanağı artacak, pek çok sorun azalacaktır.

Ülkemiz eğitim sisteminin en tartışmalı alanlarından birisi olan öğretmen yetiştirme konusunda çok sayıda ve önemli değişikliklerin olduğu görülmektedir. Ülkemizin ulusal bir öğretmen eğitimi politikası olmadığı (Saylan, 2013: 16), bilimsel verilere dayanmayan popülist yaklaşımların eğitim politikalarına yön verdiği (Güven, 2010: 19) ve öğretmen eğitimini gerçekleştiren kurumlarla istihdamını yapan kurum arasında sağlıklı bir işbirliğinin bulunmadığ1 görülmektedir (Atanur-Başkan, 2001; Kiraz \& Dursun, 2015; Şişman, 2009). Kısa sürede öğretmen yetiştirmeyi amaçlayan PFSP ise olumlu/olumsuz yanları ile en fazla tartış1lan uygulamalardandır. Doğanay ve diğerlerinin (2015: 1-15) belirttiği gibi, PFSP öğretmen eğitiminde niteliği düşürmekte ve eğitim fakültelerinin varlığını tehdit etmektedir. Sonuç olarak, bir an önce PFS programlarından vazgeçilmeli ve tutarlı bir öğretmen yetiştirme politikası geliştirilmelidir. Eğer pedagojik formasyon uygulamasına ileride yeniden dönülecekse, belli ilkeler ve kurallar çerçevesinde yürütülmelidir. Buna göre PFSP'nin yeni bir yapı ve modelle uygulanması, daha da önemlisi ögretmen yetiştirme sisteminde tutarlı bir politikanın izlenmesi gerekmektedir. Daha da önemlisi, en uygun öğretmen yetiştirme sistemine bir an önce karar verilerek bu sistemi iyileştirmek için çaba harcanmalıdır. PFSP'ye ilişkin tartışmaları Kavcar'ın (1998: 14) şu sözleri ile bitirmek anlamlı bulunmuştur: “Öğretmenlik; öğretmen olmayı önceden hiç düşünmeyenlerin, öğretmenlikle ilgili hiçbir ders almayanların ya da salt ticari kaygılarla formasyon programı düzenleyenlerden bir belge alarak yapacağı bir meslek değildir."

\section{Kaynaklar}

Altınkurt, Y., Yılmaz, K., \& Erol, E. (2014). Pedagojik formasyon programı öğrencilerinin öğretmenlik mesleğine yönelik motivasyonları. Trakya Üniversitesi Eğitim Fakültesi Dergisi, 4(1), 48-62.

Atanur-Başkan, G. (2001). Öğretmenlik mesleği ve öğretmen yetiştirmede yeniden yapılanma. Hacettepe Üniversitesi Eğitim Fakültesi Dergisi, 20, 16-25.

Atmaca, F. İ. K. (2019). Öğrencilerin pedagojik formasyon sertifika programı yeterliliklerinin belirlenmesi ve akademisyenlerin pedagojik formasyon sertifika programına yönelik görüşleri (Yayınlanmamış yüksek lisans tezi). Balıkesir Üniversitesi Sosyal Bilimler Enstitüsü, Balıkesir.

Aykaç, N., Bilgin, H., \& Toraman, Ç. (2015). Pedagojik formasyon programının öğretmen adaylarının görüşlerine göre değerlendirilmesi (Muğla Sitkı Koçman Üniversitesi Örneği). Eğitim Bilimleri Araştırmaları Dergisi, 5(1), 127-148.

Bircan, T. Ş. (2019). Pedagojik formasyon eğitimi alan tarih öğretmen adaylarının öğretmenlik mesleğine ilişkin tutumları. Kastamonu Ĕgitim Dergisi, 27(2), 589-598. 
Pedagojik Formasyon Sertifika Programına Yönelik Sorunlar ve Çözüm Önerileri: Öğretim Elemanlarının Bakış Açıısı

Creswell, J. W. (2013). Qualitative inquiry and research design: Choosing among five approaches (2nd ed.). Thousand Oaks, CA: Sage.

Çocuk, H. E., Yokuş, G., \& Tanrıseven, I. (2015) Pedagojik formasyon öğrencilerinin öğretmenliğe ilişkin özyeterlik ve metaforik algıları: Mersin Üniversitesi örneği. Mustafa Kemal Üniversitesi Sosyal Bilimler Enstitüsü Dergisi, 12, 373-387.

Demirtaş, H., \& Kırbaç, M. (2016). Pedagojik formasyon sertifika programı öğrencilerinin pedagojik formasyon eğitimine ilişkin görüşleri. Trakya Üniversitesi Eğitim Fakültesi Dergisi, 6(2), 138-152.

Doğanay, A., Akbulut Taş M., Yeşilpınar, M., Yolcu, E., Turhan-Türkkan, B., Sarı, M., Karakuş, M., Aybek, B., Sadık, F., \& Akbulut, T. (2015). Hizmet öncesi öğretmen eğitiminde model arayışı. Uluslararası Eğitim Programları ve Öğretim Çalışmaları Dergisi, 5(9), 1-21.

Durmuşçelebi, M. (2015). Öğretmenlik eğitimi programının etkililiği. Pegem Ĕgitim ve Öğretim Dergisi, 5(5), 747-766.

Dündar, H., \& Karaca, E. T. (2013). Formasyon öğrencilerinin pedagojik formasyon programına ilişkin sahip oldukları metaforlar. Gazi Üniversitesi Endüstriyel Sanatlar Eğitim Fakültesi Dergisi, 30, 19-34.

Filiz, B., \& Durnali, M. (2019). The views of pre-service teachers at an internship high school on pedagogical formation program in Turkey. European Journal of Educational Research, 8(2), 395-407.

Gönülaçar, Ş. (2016). Türkiye'de ögretmen imajı ve itibarı üzerine bir inceleme. http:// file: ///C:/Users/Lenovo/Downloads/Turkiye_de_Ogretmen_Imaji_ve_Itibari_Uze\%20(1).pd f. 9.07.2019 tarihinde erişilmiş̧ir.

Gülhan, F. (2020). Öğretmenlerin pedagojik formasyon derslerinden yararlanabilme düzeyleri (Yayınlanmamış yüksek lisans tezi). Uşak Üniversitesi Lisansüstü Eğitim Enstitüsü, Uşak.

Gürol, M., Türkan, A., \& Som, İ. (2018). Pedagojik formasyon sertifika programının değerlendirilmesi. Elektronik Sosyal Bilimler Dergisi, 17(65), 103-122.

Güven, D. (2010). Profesyonel bir meslek olarak Türkiye'de öğretmenlik. Boğaziçi Üniversitesi Ë̆itim Dergisi, 27(2), 13-21.

İncik, E. Y., \& Akay, C. (2014). Mersin Üniversitesi Eğitim Fakültesi ve pedagojik formasyon öğretmen adaylarının öğretmenlik mesleği yeterliklerine ilişkin görüşleri. Ögrretmen Yetiştirme Politika ve Sorunları Uluslararası Sempozyumu IV-ISPITE2014 Bildiriler Kitabl (s. 75-77). Ankara: Hacettepe Üniversitesi.

İzci, E. (1999). Ortaöğretim kurumlarında görev yapan öğretmenlerin öğretmenlik meslek bilgisi yeterliklerinin bazı değişkenlere göre incelenmesi (Yayınlanmamış doktora tezi). İnönü Üniversitesi Sosyal Bilimler Enstitüsü, Malatya.

Kanadlı, S., \& Karakuş, F. (2016). Formasyon programının öğretmen adaylarının mesleki öz yeterlik inançlarına ve tutumlarına etkisi: Bir karma yöntem araştırması. Journal of Human Sciences, 13(3), 3807-3826.

Kavcar, C. (1998). Türkçe eğitimi ve sorunları. Ankara Üniversitesi TÖMER Dil Dergisi, 65, 517. 
Kılınç, A. Ç., Kılcan, B., \& Çepni, O. (2018). Pedagojik formasyon eğitimi sertifika programına katılan edebiyat fakültesi öğrencilerinin öğretmenlik uygulaması deneyimlerinin incelenmesi: Fenomenolojik bir çözümleme. Eğitimde Nitel Araştırmalar Dergisi, 6(1), 113-132.

Kiraz, Z., \& Dursun, F. (2015). Pedagojik formasyon eğitimi alan öğretmen adaylarının aldıkları eğitime ilişkin algıları. Mersin Üniversitesi Eğitim Fakültesi Dergisi, 11(3), 1008-1028.

Köse, A. (2017). Pedagojik formasyon eğitiminde görevli akademisyenlere göre pedagojik formasyon uygulaması: sorunlar, çözüm önerileri. Journal of Kırşehir Education Faculty, 18(2), 709-732.

Memduhoğlu, H. B., \& Topsakal, C. (2008). Quality and problems of teacher education graduate programs according to the views of students and faculty members. Ege Journal of Education, 9(1), 95-129.

Miles, M. B., \& Huberman, A. M. (1994). Qualitative data analysis: An expanded source book (2nd ed.). Thousand Oaks, CA: Sage.

Öztürk, B., Doğan, O., \& Koç, G. (2005). Eğitim fakültesi öğrencileri ile fen-edebiyat fakültesi mezunlarının öğretmenlik mesleğine yönelik algılarının karşılaştırılması. Türk Eğitim Bilimleri Dergisi, 3(1), 1-22.

Patton, M. Q. (2014). Nitel araştırma ve değerlendirme yöntemleri (Çev. Ed. M. Bütün \& S. Beşir Demir). Ankara: Pegem.

Safran, M. (2014). Eğitim fakülteleri, öğretmen yetiştirme süreci ve yeni arayışlar. Öğretmen Yetiştirme Politika ve Sorunları Uluslar Arası Sempozyumu IV-ISPITE Bildiriler Kitabı (s. 2-3). Ankara: Hacettepe Üniversitesi.

Sağlam, A. Ç. (2015). Pedagojik formasyon sertifikası programının etkililiğinin öğrenci görüşlerine göre değerlendirilmesi. Kırıkkale Üniversitesi Sosyal Bilimler Dergisi, 5(2), 64-73.

Saylan, N. (2013). Sürekli değiştirilen öğretmen yetiştirme sistemi. Uluslararası Eğitim Programları ve Öğretim Çalışmaları Dergisi, 3(6), 9-19.

Sürücü, A. (1997). Öğretmenlik formasyonu alan öğrencilerin ögrretmenlik mesleğine yönelik tutumları (S.Ü.E.F. yaz kursu örneği) (Yayınlanmamış yüksek lisans tezi). Selçuk Üniversitesi Sosyal Bilimler Enstitüsü, Konya.

Şen, Z., \& Göğüş, N. (2011). Pedagojik formasyon sertifika programı katılımcıları ile eğitim fakültesi öğrencilerinin öğretmenlik mesleğine ilişkin tutumlarının karşılaştırılması. $I$. Uluslararası Ĕgitim Programları ve Öğretim Kongresi. Eskişehir: Anadolu Üniversitesi, Bildiri Özetleri. https://www.pegem.net/akademi/kongrebildiri_detay.aspx?id=130209. adresinden 17.10.2020 tarihinde indirilmiştir.

Şenel, E. A. (1999). Öğretmenlik sertifikası programına katılan öğretmen adaylarının ögrretmenlik mesleğine yönelik tutumlarına ögretmenlik uygulamalarının etkisi (Yüksek lisans tezi). Anadolu Üniversitesi Sosyal Bilimler Enstitüsü, Eskişehir.

Şişman, M. (2009). Öğretmen yeterlilikleri: Modern bir söylem ve retorik. İnönü Üniversitesi Eğitim Fakültesi Dergisi, 10(3), 63-82.

Talim ve Terbiye Kurulu. (2017). Öğretmenlik alanlarl, atama ve ders okutma esaslart. http://ttkb.meb.gov.tr/www/80-sayili-karar/icerik/19 adresinden 15.10.2020 tarihinde indirilmiştir. 
Pedagojik Formasyon Sertifika Programına Yönelik Sorunlar ve Çözüm Önerileri: Öğretim Elemanlarının Bakış Açısı

Taneri, P. O. (2016). Öğretmen adaylarının pedagojik formasyon sertifika programının niteliği hakkındaki görüşleri (Çankırı ili örneği). Kastamonu Ĕ̆itim Dergisi, 24(3), 997-1014.

Tanrıkulu, M. (2017). Türkiye'de fen-edebiyat ve eğitim fakültesi ikileminde öğretmen yetiştirme ve pedagojik formasyon uygulamaları. Akademik Bakış Dergisi, 59, 264-275.

Tepeli, Y., \& Caner, M. (2014). Pedagojik formasyon programı öğrencilerinin öğretmenlik uygulaması ile ilgili görüşleri. Eğitim Bilimleri Araştırmaları Dergisi, 4(2), 313-328.

Yapıcı, M., \& Yapıcı, Ş. (2013). Öğretmen adaylarının pedagojik formasyona ilişkin metaforlar1. Turkish Studies, 8(8), 1421-1429.

Yıldırım, İ., \& Vural, F. Ö. (2014). Türkiye'de öğretmen yetiştirme ve pedagojik formasyon sorunu. Journal of Teacher Education and Educators, 3(1), 73-90.

Yıldırım, K., Alpaslan, M. M., \& Ulubey, Ö. Y. (2019). Pedagojik formasyon eğitimi sertifika programındaki öğretmen adaylarının öğretmenlik mesleğine yönelik motivasyonlarının incelenmesi. Bolu Abant İzzet Baysal Üniversitesi Ĕ̈itim Fakültesi Dergisi, 19(1), 428439.

Yıldırım, A., \& Şimşek, H. (2013). Sosyal bilimlerde nitel araştırma yöntemleri. Ankara: Seçkin Yayıncilik.

Yılmaz, G. (2015). Pedagojik formasyon yoluyla öğretmen yetiştirme uygulamalarında karşılaşılan güçlükler ve mezunların istihdamlarının değerlendirilmesi (Yayınlanmamış yüksek lisans tezi). Fırat Üniversitesi Eğitim Bilimleri Enstitüsü, Elazığ.

Yiğit, Ş. (2018). Pedagojik formasyon ĕgitimi alan ortaöğretim öğretmen adaylarının meslek tercih nedenlerinin bazı değişkenlere göre incelenmesi (Yayınlanmamıș yüksek lisans tezi). Cumhuriyet Üniversitesi Eğitim Bilimleri Enstitüsü, Sivas.

Yükseköğretim Kurulu (YÖK). (1998). Eğitim fakültesi öğretmen yetişstirme lisans programları. Ankara: Yükseköğretim Kurulu.

Yükseköğretim Kurulu (YÖK). (2007). Öğretmen yetiştirme ve eğitim fakülteleri (1982-2007) (Öğretmenin üniversitede yetiştirilmesinin değerlendirilmesi). Ankara: Yükseköğretim Kurulu. http://www.yok.gov.tr/web/guest/yayinlarimiz adresinden 02.12.2015 tarihinde erişilmiştir.

Yüksek Öğretim Kurulu (YÖK). (2012). 2012-2013 Öğretim yılı pedagojik formasyon sertifika programl. www.yok.gov.tr adresinden 06.12.2019 tarihinde erişilmiştir.

Yükseköğretim Kurulu (YÖK). (2015). Pedagojik formasyon eğitimi sertifika programları hakkında açıklama. Ankara: Yükseköğretim Kurulu. http://www.yok.gov.tr/documents/10279/19836547/Pedagojik_Formasyon_Egiti mi_Sertifika_Programlari_Hakkinda_Aciklama.pdf adresinden 10.12.2019 tarihinde erişilmiştir.

Yükseköğretim Kurulu (YÖK). (2018). 20.01.2015 tarihli yükseköğretim yürütme kurulu toplantısında alınan kararla 2014-2015 eğitim-öğretim yılı bahar dönemi pedagojik formasyon eğitimi sertifika programına izin verilen üniversiteler ve kontenjanlar. https://www.yok.gov.tr/Documents/Kurumsal/egitim ogretim dairesi/Pedagojik-

Formasyonla-ilgili-sikca-sorulan sorular/25092015\%20Pedagojik\%20Formasyon\%20ile\%20\%C4\%B0lgili\%20Duyuru.p df adresinden 8.10.2019 tarihinde erişilmiştir. 
Yükseköğretim Kurulu (YÖK). (2020). Pedagojik formasyon sertifika eğitimi. https://www.yok.gov.tr/kurumsal/idari-birimler/egitim-ogretim-dairesi/pedagojikformasyonla-ilgili-sss adresinden 15.11.2020 tarihinde erişilmiştir.

Yüksel, S. (2011). Fen-Edebiyat Fakültesi öğretim üyelerinin öğretmen yetiştirme sistemine ilişskin düşünceleri (Uludağ üniversitesi fen-edebiyat fakültesi örneği). Kuram ve Uygulamada Ĕ̈itim Bilimleri, 11(1), 179-192.

\section{EXTENDED ABSTRACT}

\section{Introduction}

In Turkey since 1982, Faculties of Educational Sciences are responsible for teacher education. However, there is another application, which allows students of Science and Literature Faculties to be teachers, stands out and is followed in Turkey. With Pedagogical Formation Certificate Program (PFCP), any person having a licence degree may participate this program and is able to be a teacher. Pedagogical Formation Certificate Program applied in the Faculties that are not design for raising teachers brought many problems. For example, there are undergraduates more than its needed in the field of branch teachers for secondary education. This should not be considered only as a quantitative increase. Qualitative aspect of this education and the efficency of these teacher candidates should be examined. Between 1992-2020 PFCP was cancelled for many times, and later it was put into force again. In our country, contradicting changes made in teacher education became a hindrance on raising qualified teachers.

\section{Purpose}

The purpose of this study is that to examine the efficiency of the program, reveal problems, and give suggestions about increasing the quality of PFCP in the context of opinions of teaching staffs giving lectures in scope of PFCP in a public university in Ankara, in case it is put into force again in the future.

\section{Method}

Opinions of teaching staffs related to pedagogical formation education examined throughly, therefore, one of the quantitave research method, Phenomonology is used in the study. Working group of this research consists of teaching staffs of Gazi University, Faculty of Education who are giving lectures in PFCP. Criterion and maximum variation methods are used for selecting participants. Working group of this research consists of 11 male and 6 female, in total 17 teaching staffs from eight different department. Data of the research is gathered from semistructured interview forms. In the interview forms, being fit for purpose of PSCP, its necessity, how lectures are performed, and assessed, attitude of students toward lectures, general problems in the program, question about suggestions are examined. Data is gathered and recorded in face to face meetings with participants. Meetings took aproximately 35-40 minutes. Content analysis is used in the data analysis. The content analysis is about grouping certain themes and codes according to similarities. While preparing content analysis, data is coded for each interview, and these codes are classified and lastly, tables were created for codes and catagories (themes).

\section{Findings}

Findings obtained from data analysis of the research, comments on findings, are catagorized as purpose and neccessity of PFCP, suggestions, and problems relating to the program. Teaching staffs stated that the main purpose of PFCP is to raise good teachers but it doesn't achieve this 
purpose at all. Many teaching staffs believe that PFCP is unneccesary, even though they are giving lectures in the program. Problems of PFCP are mainly about teaching-learning process, student, lecture contents, assessment, teaching practice, general problems and teaching staffs. It is detected that lectures are arranged at late hours, classes are crowded and mostly direct instruction method is used, students participate the program not to be a teacher but to recieve a certificate/diploma, they are in general reluctant and tired, they lack of basic information, practical lessons are very little, pre-requisite lessons are not given orderly, lessons are mainly theoretical, in general, mutiple choice tests are used for the assessment, teaching practice hours are not enough, some of teaching staffs give training in the program only for income. Similarly, suggestions in this study focuses on learning-teaching process, PF program structure, lesson contents, teaching practices and teaching staffs. Teaching staffs gave suggestion to abowmentioned problems as follows: practical lesson hours should increase, lectures should be programmed at early hours, classes should not be mixed and they should be divided according to departments, program duration should be longer, seriousness and motivation of students should be increased, attention should be paid to pre-requisite lessons, Professional and eager teaching staffs should provide lectures.

\section{Discussion}

Results of this study reveals the opinions of teaching staffs regarding the necessity of PFCP, and problems and suggestions about the program. According to teaching staffs, main purpose of PFCP should be raising qualified teachers, however it is understood that the program does not serve this purpose or ensure teacher qualifications. Teaching staffs believe that the main purpose of performing PFCP is to give teaching certificate to science- literature graduates and by this way, facilitate them to be employed. According to two teaching staffs, PFCP is opened because of economical concerns which is enabling universities and teaching staffs gain profit. Based on stated problems, it may be uttered that PFCP does not provide an education environment that ensure effective teaching skills.

\section{Conclusion and Suggestions}

It is understood that there has been a big number of changes about one of the most contraversial topic, raising teacher in our country. Unfortunately, it is observed that there is not a national teacher education policy, education policies are affected by groundless populist approaches, and there is not a healthy cooperation between educational institutions raising teachers and employing establishments. On the other hand, PFCP, which is giving education on being teacher in a short term, is one of the most contraversial application. As a result, PFCP should be cancelled as soon as possible If pedagogical formation will put into force again in the future, there has to be certain principles and rules. Moreover, best system for raising teachers should be decided and effort should be paid to enhance it.

\section{Etik Kurul İzin}

Çalışmanın verileri 2020 yılı öncesinde toplanmıştır. Araştırmaya katılan öğretim elemanlarına araştırmanın konusu, amacı ve tüm bilgilerin gizlilik ve mahremiyet ilkelerine uygun olarak gizli tutulacağı konusunda gerekli açıklamalar yapılarak, yazılı onamları alınmıştır. 